\title{
David Oliver: Social care-back to an uncertain future
}

\author{
David Oliver consultant in geriatrics and acute general medicine
}

Berkshire

If I'd been writing this column in early 2010, on the threshold of a new five year parliament, I'd have called for a credible long term solution for social care in England, lamented the lack of meaningful action to date, and doubted the political commitment or public will to change.

Sometimes, the more things change, the more they stay the same, and so it is with social care. Three general elections later, at the start of this new decade I could virtually cut and paste the same introduction. Recent history makes me doubt the future.

The recommendations of the 1999 Royal Commission on Long Term Care for older people were largely ducked by Labour in the 2000 NHS plan. ${ }^{12}$ And in early 2010 the Labour government published a white paper on the future of social care funding, Building the National Care Service, ${ }^{3}$ weeks before losing the general election. It proposed services free at the point of need with a consistent national offer, akin to the NHS.

Details on how it would be funded were vague. The Conservative Party wouldn't commit to a cross party debate or solution. The right wing press whipped up fearmongering headlines about a "death tax" and its impact on voters. ${ }^{4}$ The policy was dropped after the coalition government took over in May 2010. However, in July 2010 that coalition established the Commission on Funding of Care and Support, led by the economist Andrew Dilnot, who was asked to find a way to create an affordable and sustainable funding system.

In $2011^{5}$ the commission emphasised the poor financial risk sharing and shared protection in social care, as well as the significant financial risk to patients with assets above the means testing threshold. It proposed a system where means tested support was extended but with a cap on the lifetime care costs people could expect to pay.

This policy would also require additional funding, a willing private social care insurance market, and political commitment. All were in short supply. After the Conservatives' 2015 general election victory the partial implementation of Dilnot's proposals-pushed by the Liberal Democrats in the coalition-were quietly dropped.

During the 2017 election campaign the Conservative Party, now led by Theresa May, made further proposals on social care funding. These majored on posthumous use of assets to pay for care-sparking media outrage and concerns over a "dementia tax" and criticism from Dilnot himself. ${ }^{67}$ Even though some of the ideas were progressive, the proposal was dropped.

May's government subsequently announced a green paper $^{8}$ to identify sustainable solutions for social care funding and provision, but amid Brexit uncertainty the initial report was serially delayed and has yet to be seen in public.

\section{Papering over the cracks}

Meanwhile, since the 2010 spending round, sustained cuts to local government support grants from central government have hit social care services hard, with real terms spending still well below 2010 levels—despite various short term cash injections and a new social care "precept" allowing local authorities to raise more money through local council tax. ${ }^{910}$ The number of adults receiving social care support has dropped in that decade. ${ }^{11}$

The well regarded 2014 Care Act $^{12}$ set out a range of standard entitlements for assessment and support, both for adults with needs and for their carers, but delivering this requires adequate resourcing and staff. The social care workforce faces growing workforce gaps, provider market failure, and threats from new threshold proposals on immigration. ${ }^{13}$

What, then, of the new era of Johnson and Brexit? Well, the Queen's speech in January 2020 promised a cross party approach to social care solutions. And the prime minister promised "a solution within the next 12 months." 14

We've heard such promises before, and, although we currently spend around 13 times more on the NHS than on social care, fears about future affordability and the electoral fallout from costs for individuals (or their inheritance) will rear their heads. Perhaps the issue simply isn't all that important to voters until the need for social care happens to them or their families, so serial deferrals are just realpolitik. However, my trip through recent history doesn't give me much hope for the near future. 
1 Royal Commission on Long Term Care. With respect to old age: long-term care-right and responsibilities. 1999. https://navigator.health.org.uk/content/respect-old-age-longterm-care-\%E2\%80\%93-rights-and-responsibilities-1999.

2 Department of Health. The NHS Plan: a plan for investment, a plan for reform. Jul 2000. https://navigator.health.org.uk/content/nhs-plan-plan-investment-plan-reform-2000.

3 Department of Health and Social Care. Building the national care service. 30 Mar 2010. https://www.gov.uk/government/publications/building-the-national-care-service.

4 Watt N. Spectre of "death tax" haunts Andy Burnham's care revolution. 30 Mar 2010. https://www.theguardian.com/politics/2010/mar/30/death-tax-haunts-andy-burnham-carerevolution.

5 King's Fund. Briefing: the Dilnot Commission report on social care. 13 Jul 2011. https:// www.kingsfund.org.uk/sites/default/files/field/field_publication_file/briefing-dilnotcommission-social-care-jul11.pdf.

6 Weaver M. Tory social care plans will leave people helpless, says former adviser. Guardian 2017 May 18. https://www.theguardian.com/politics/2017/may/18/tory-social-care-planexample-market-failure-andrew-dilnot.

7 Mason R, Campbell D. Theresa May under pressure over "dementia tax" social care shakeup. Guardian 2017 May 21. https://www.theguardian.com/politics/2017/may/21/ theresa-may-under-pressure-over-dementia-tax-social-care-shakeup.
8 House of Commons Library. Debate on the address: health and social care. 13 Jan 2020. https://researchbriefings.parliament.uk/ResearchBriefing/Summary/CDP-2020-0001.

9 King's Fund. Key facts and figures about adult social care. 20 Nov 2019. https://www. kingsfund.org.uk/audio-video/key-facts-figures-adult-social-care.

10 Oliver D. David Oliver: England's social care models harm the poorest areas. BMJ 2018;361:k2745. https://www.bmj.com/content/361/bmj.k2745. 10.1136/bmj.k2745 29950506

11 King's Fund. What's your problem, social care? The eight key areas for reform. 5 Nov 2019. https://www.kingsfund.org.uk/publications/whats-your-problem-social-care.

12 Care Act 2014. http://www.legislation.gov.uk/ukpga/2014/23/contents/enacted.

13 Hemmings N. A public policy blind spot? The possible futures of the social care workforce. Nuffield Trust. 4 Feb 2020. https://bit.ly/3cfSTOC.

14 Zeffman H. Boris Johnson: Give me one year to find social care solution. Times $2020 \mathrm{Jan}$ 15. https://www.thetimes.co.uk/article/boris-johnson-give-me-one-year-to-find-social-caresolution-g303rross. (Login needed.)

Published by the BMJ Publishing Group Limited. For permission to use (where not already granted under a licence) please go to http://group.bmj.com/group/rights-licensing/ permissions 